\title{
Anastrepha species (Diptera: Tephritidae), their hosts and parasitoids in southern Amapá State, Brazil
}

\author{
Ricardo Adaime da Silva ${ }^{1,5}$, Adilson Lopes Lima ${ }^{1}$, Samara Larissa Oliveira Xavier ${ }^{2}$, \\ Wilson Rodrigues da Silva ${ }^{3}$, Cláudia Fidelis Marinho ${ }^{4}$ \& Roberto Antonio Zucchi ${ }^{4}$ \\ ${ }^{1}$ Embrapa Amapá - EMBRAPA, Rod. JK, Km 05, CEP 68903-419, Macapá, AP, Brazil \\ ${ }^{2}$ Universidade Federal do Amapá - UNIFAP, Rod. JK, Km 02, CEP 68902-280, Macapá, AP, Brazil \\ ${ }^{3}$ Secretaria de Estado da Educação do Amapá - SEED, Av. FAB, s/n, Centro, CEP 68906-970, \\ Macapá, AP, Brazil \\ ${ }^{4}$ Escola Superior de Agricultura “Luiz de Queiroz” - ESALQ, Universidade de São Paulo - USP, \\ Av. Pádua Dias, 11, CEP 13418-900, Piracicaba, SP, Brazil \\ ${ }^{5}$ Corresponding author: Ricardo Adaimeda Silva, e-mail: adaime@cpafap.embrapa.br
}

SILVA, R.A., LIMA, A.L., XAVIER, S.L.O., SILVA, W.R., MARINHO, C.F. \& ZUCCHI, R.A.Anastrepha species (Diptera: Tephritidae), their hosts and parasitoids in southern Amapá State, Brazil. Biota Neotrop. 11(3): http://www.biotaneotropica.org.br/v11n3/en/abstract?short-communication+bn03511032011

\begin{abstract}
This work was carried out to record the species of Anastrepha, their host plants and associated parasitoids in Laranjal do Jari and Vitória do Jari, Amapá State. Fleshy fruits of 17 species of 13 families were sampled, from February to July of 2006, in main districts of both municipalities. Nine species of Anastrepha and six species of braconid parasitoids were sampled during this study.

Keywords: Amazon, Fruit flies, Hymenoptera, Braconidae, Tephritoidea.

SILVA, R.A., LIMA, A.L., XAVIER, S.L.O., SILVA, W.R., MARINHO, C.F. \& ZUCCHI, R.A. Espécies de Anastrepha (Diptera: Tephritidae), seus hospedeiros e parasitoides no sul do estado do Amapá, Brasil. Biota Neotrop. 11(3): http://www.biotaneotropica.org.br/v11n3/pt/abstract?short-communication+bn03511032011

Resumo: O presente trabalho foi realizado com o objetivo de registrar as espécies de Anastrepha, suas plantas hospedeiras e parasitoides associados nos municípios de Laranjal do Jari e Vitória do Jari, estado do Amapá. Frutos carnosos de 17 espécies de 13 famílias foram amostrados, de fevereiro a julho de 2006, nos principais distritos dos dois municípios. Nove espécies de Anastrepha e seis espécies de braconídeos parasitoides foram coletadas durante o estudo.

Palavras-chave: Amazônia, Moscas-das-frutas, Hymenoptera, Braconidae, Tephritoidea.
\end{abstract}




\section{Introduction}

The majority of studies on fruit flies (Diptera: Tephritidae) from tropical regions focus on species of economic importance and there is poor information on their native hosts (Uramoto et al. 2008). However, this knowledge is relevant to the understanding of tephritid behavior in nature (Aluja 1999). Surveys on fruit flies, their hosts and parasitoids are fundamental for a better understanding of the biology and ecology of these insects (Zucchi 2000). Studies on tephritid populations in native areas adjacent to commercial orchards should therefore be encouraged (Deus et al. 2009). The reported geographic distribution and host plants in an area should be included in catalogs, thus producing the basic reference for technicians involved in quarantine activities (Zucchi 2000).

In Amapá State, studies on fruit flies have been intensified in recent years. Twenty-five species of Anastrepha have been reported, with considerable amounts of information on their hosts and parasitoids (Silva et al. 2011). However, very little information is available on the southern part of the State, and no systematized survey has ever been conducted in that region. The species previously recorded in that area are Anastrepha distincta Greene, A. turpiniae Stone, and A. striata Schiner in Laranjal do Jari, and A. striata in Vitória do Jari, besides the parasitoid Doryctobracon areolatus (Szépligeti) in Vitória do Jari (Creão 2003).

The purpose of this work was to record the species of Anastrepha found on cultivated and wild hosts, and their parasitoids in the southern part of Amapá State, Brazil.

\section{Material and Methods}

Fruits were sampled from February to July 2006, in the municipalities of Laranjal do Jari and Vitória do Jari, in the southern part of the State of Amapá. Random fruits ripening or ripe were collected from each plant or taken from ground if recently fallen, in municipalities and neighboring communities namely Tira-Couro, Água Branca do Cajari, Martins, Marinho, São Benedito, and Ramal Sombra da Mata (Laranjal do Jari), Ramal do Marapi, Ramal da Horta, and Ramal de Vitória do Jari (Vitória do Jari). Fruits were stored in coolers, covered with organza cloth, then transported to the Laboratory of Entomology at Embrapa Amapá, in Macapá.

In laboratory, the fruits were counted, weighed and placed on plastic trays over a layer of sterilized wet sand. Trays were covered with organza cloth, fastened in place with rubber bands, and examined every three days. Puparia were transferred to transparent plastic flasks ( $8 \mathrm{~cm}$ diameter) conditioned with a thin layer of wet vermiculite, and covered with organza fastened with a perforated lid, then placed in climate controlled chambers under temperature $\left(27 \pm 0.5^{\circ} \mathrm{C}\right)$, relative humidity $(70 \pm 5 \%)$ and photophase (12 hours). Observations were made daily. Fruit flies and parasitoids were stored in glass flasks containing $70 \%$ ethanol.

\section{Results and Discussion}

\section{Fruit flies}

Seventeen plant species of 13 families were sampled (Tables 1 to 3). However, only seven species were infested by fruit flies (guava, Psidium guajava; ingá-cipó, Inga edulis; hog plum, Spondias mombin; goiaba-de-anta, Bellucia grossularioides; quina, Geissospermum argenteum; abiu, Pouteria caimito; and manilkara, Manilkara huberi) (Tables 1 and 2).

Nine species of Anastrepha were collected: Anastrepha antunesi Lima, Anastrepha atrigona Hendel, Anastrepha coronilli Carrejo \& González, Anastrepha distincta Greene, Anastrepha fraterculus
Wiedemann, Anastrepha obliqua Macquart, Anastrepha serpentina Wiedemann, Anastrepha sororcula Zucchi, and Anastrepha striata Schiner (Tables 1 and 2). All mentioned species were collected in the municipality of Laranjal do Jari, from 3,890 fruits $(99.0 \mathrm{~kg})$ sampled (Table 1). In Vitória do Jari, only A. atrigona, A. coronilli, A. distincta and $A$. striata were obtained from 831 fruits (18.7 kg) (Table 2).

All of the Anastrepha species collected had been previously reported from Amapá (Silva et al. 2011). Seven species constitute new reports for Laranjal do Jari: A. antunesi, A. atrigona, A. coronilli, A. fraterculus, A. obliqua, A. serpentina, and A. sororcula (Table 1). Three species were collected in Vitória do Jari for the first time: A. atrigona, A. coronilli, and A. distincta (Table 2).

Guava was the host with most Anastrepha species (Table 1). In Amapá, it has been reported as a host for nine species (Silva et al. 2011). Anastrepha striata was the predominant species in guava from Laranjal do Jari and the only species obtained from guava in Vitória do Jari (Tables 1 and 2). This species has been the predominant tephritid found in guava throughout the State of Amapá (Silva \& Silva 2007, Silva et al. 2007a, 2010, Deus et al. 2009).

The highest infestation rates were observed in fruits of quina, with an average of 614.9 puparia/kg in Laranjal do Jari (Table 1) and 162.0 puparia/kg in Vitória do Jari (Table 2). In a single sample of quina from Laranjal do Jari, a total of 1,047.3 puparia $/ \mathrm{kg}$ was counted. In hosts of economic relevance, the infestation rates were different in each municipality, for example, ingá-cipó yielded 9.5 puparia $/ \mathrm{kg}$ in Vitória do Jari and 56.1 puparia/kg in Laranjal do Jari, and guava had 23.7 puparia/kg in Laranjal do Jari and 53.4 puparia/kg in Vitória do Jari.

Anastrepha atrigona was sampled in quina, A. coronilli in goiaba-de-anta, $A$. distincta in ingá-cipó, and $A$. serpentina in abiu and manilkara, as already reported from other municipalities of Amapá (Silva et al. 2011). The rate of infestation found in quina (614.9 puparia/kg) was higher than the rate reported by Xavier et al. (2006) in the same municipality (525.9 puparia/kg) and by Deus et al. (2009) in two municipalities in central Amapá (241.02 and 422.22 puparia/kg).

Plant species considered to be economically relevant to the State of Amapá, such as hog plum (Spondias mombin), ingá-cipó (Inga edulis), guava (Psidium guajava), and abiu (Pouteria caimito), had widely variable infestation rates by fruit flies across different locations in the State. For example, if compared with the data reported by Silva et al. (2010), the infestation rates observed in this work in guava were lower than those reported for the municipalities of Macapá (406.25 puparia/kg), Porto Grande (446.71 puparia/kg) and Mazagão (536.00 puparia/kg). In ingá-cipó and abiu, the rates reported here were lower than those reported for Mazagão (152.72 and 195.33 puparia/kg, respectively). On the other hand, the infestation rate in hog plum (58.0 puparia/kg in Laranjal do Jari) was lower than the rate reported in Macapá (141.8 puparia/kg) by Silva et al. (2005).

Ten species of seven plant families were not infested by Anastrepha (Table 3). However, among these species, cashew (Anacardium occidentale), biribá (Rollinia mucosa), ajuru (Chrysobalanus icaco), muruci (Byrsonima crassifolia), jaca (Artocarpus heterophyllus), star fruit (Averrhoa carambola) and orange (Citrus sinensis) have already been reported as hosts of A. striata in Amapá. Anastrepha striata is the most abundant and polyphagous tephritid species in the State ( 25 hosts in 16 botanical families), with a clear preference for Myrtaceae (Silva et al. 2011).

\section{Parasitoids}

In Laranjal do Jari, a total of 188 parasitoids (Braconidae) belonging to six species were collected: Doryctobracon areolatus (Szépligeti), Doryctobracon crawfordi (Viereck), Asobara anastrephae 


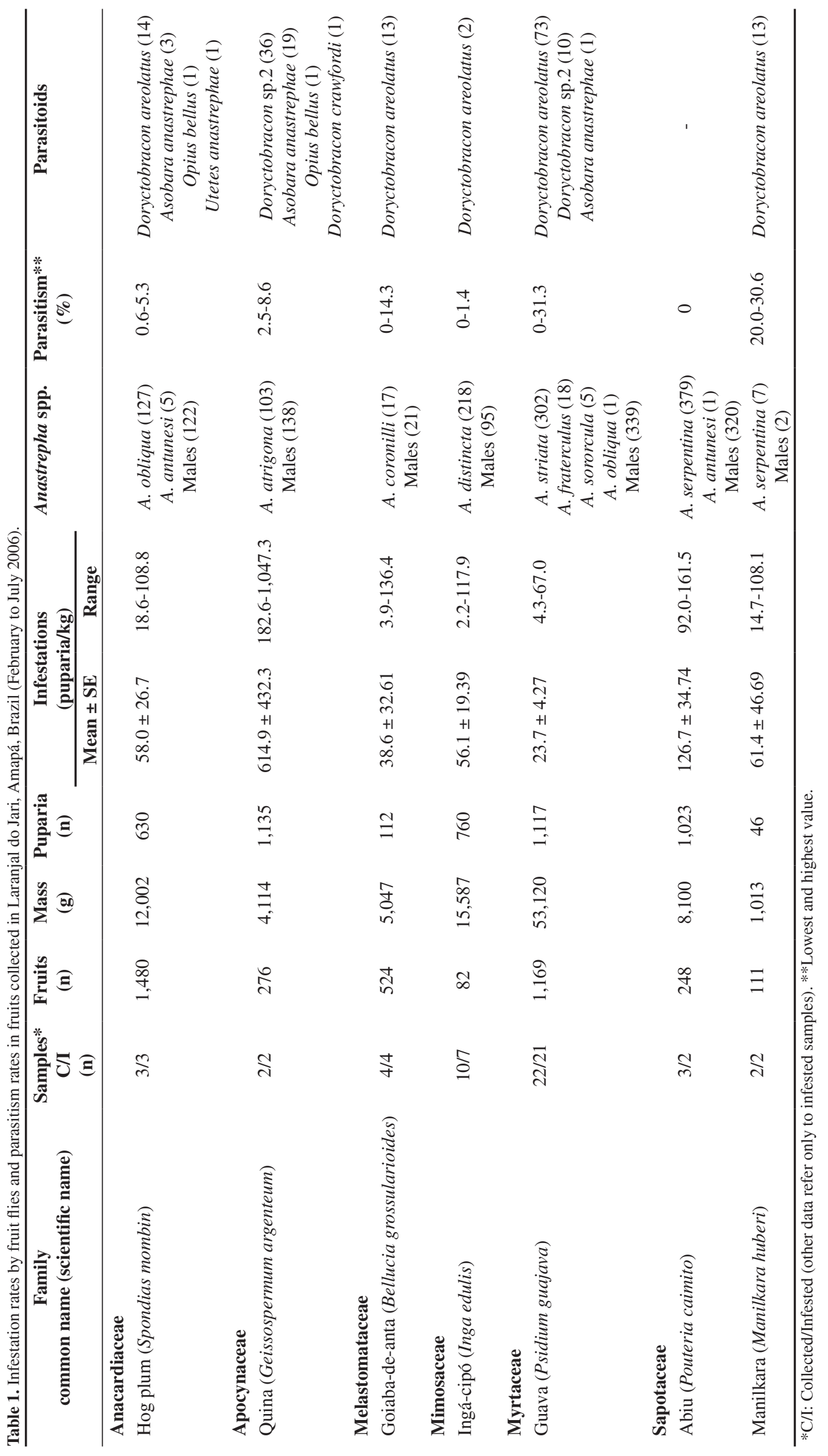


Silva, R.A. et al.

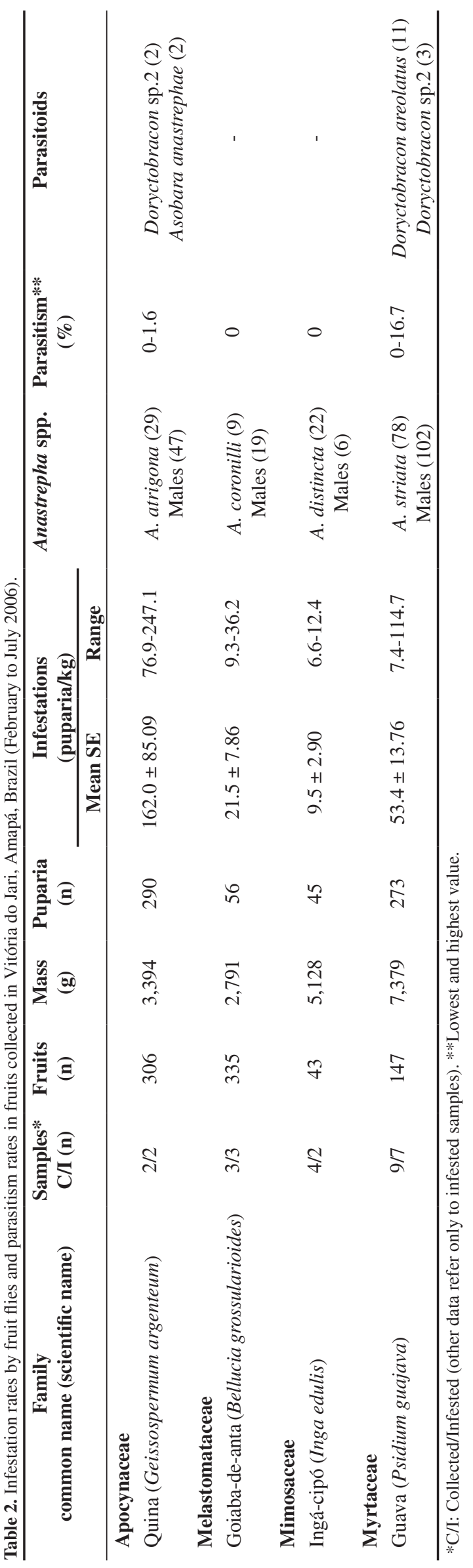


Table 3. Species not infested by fruit flies (February to July 2006).

\begin{tabular}{|c|c|c|c|c|c|c|}
\hline \multirow{2}{*}{$\begin{array}{c}\text { Families } \\
\text { Common names (scientific names) }\end{array}$} & \multicolumn{3}{|c|}{ Laranjal do Jari } & \multicolumn{3}{|c|}{ Vitória do Jari } \\
\hline & $\begin{array}{l}\text { Samples } \\
\text { (n) }\end{array}$ & $\begin{array}{l}\text { Fruits } \\
\text { (n) }\end{array}$ & $\begin{array}{c}\text { Mass } \\
(\mathrm{g})\end{array}$ & $\begin{array}{l}\text { Samples } \\
\text { (n) }\end{array}$ & $\begin{array}{l}\text { Fruits } \\
\text { (n) }\end{array}$ & $\begin{array}{c}\text { Mass } \\
(\mathrm{g})\end{array}$ \\
\hline \multicolumn{7}{|l|}{ Anacardiaceae } \\
\hline Cashew (Anacardium occidentale) & 3 & 26 & 1,645 & - & - & - \\
\hline Mango (Mangifera indica) & 2 & 28 & 5,677 & - & - & - \\
\hline \multicolumn{7}{|l|}{ Annonaceae } \\
\hline Biribá (Rollinia mисоsa) & 1 & 7 & 1,061 & - & - & - \\
\hline Graviola (Annona muricata) & - & - & - & 1 & 1 & 920 \\
\hline \multicolumn{7}{|l|}{ Chrysobalanaceae } \\
\hline Ajuru (Chrysobalanus icaco) & - & - & - & 1 & 366 & 2,152 \\
\hline \multicolumn{7}{|l|}{ Malpighiaceae } \\
\hline Acerola (Malpighia punicifolia) & 1 & 58 & 249 & 1 & 37 & 107 \\
\hline Muruci (Byrsonima crassifolia) & 1 & 96 & 389 & 5 & 732 & 3,613 \\
\hline \multicolumn{7}{|l|}{ Moraceae } \\
\hline Jaca (Artocarpus heterophyllus) & 1 & 1 & 3,225 & - & - & - \\
\hline \multicolumn{7}{|l|}{ Oxalidaceae } \\
\hline Star fruit (Averrhoa carambola) & 6 & 143 & 10,097 & 2 & 29 & 2,609 \\
\hline \multicolumn{7}{|l|}{ Rutaceae } \\
\hline Orange (Citrus sinensis) & 4 & 70 & 8,032 & 1 & 7 & 1,046 \\
\hline
\end{tabular}

(Muesebeck), Opius bellus Gahan, Utetes anastrephae (Viereck), and one new species of Doryctobracon not formally described to date [Doryctobracon sp.2 in Marinho's thesis (2009)] (Table 1). Doryctobracon crawfordi was recently recorded from Brazil (States of Amapá and Roraima) (Zucchi et al. 2011). Only 14 parasitoids were registered in Vitória do Jari, which belonged to three species: D. areolatus, A. anastrephae, and Doryctobracon sp.2 (Table 2).

Doryctobracon areolatus was the predominant parasitoid species in both municipalities (Tables 1 and 2). The second most abundant parasitoids were Doryctobracon sp.2 and Asobara anastrephae in both municipalities. In Laranjal do Jari, few specimens of Opius bellus and $U$. anastrephae and only one specimen of Doryctobracon crawfordi were collected. Doryctobracon areolatus is the most abundant braconid parasitoid of fruit flies in the State of Amapá (Silva \& Silva 2005, Silva et al. 2007a, b, 2010, Deus et al. 2009), and is also considered to be the most widely distributed throughout Brazil (Leonel Junior et al. 1995, Canal \& Zucchi 2000) and Latin America (Ovruski et al. 2000). The predominance of this species compared to other native parasitoids may be associated not only with its greater ability to locate hosts, but also its ability to infest larvae at early instars (Matrangolo et al. 1998).

The highest parasitism rate was found in guava, in Laranjal do Jari (Table 1). The rate observed in this work $(31.3 \%)$ was higher than in Mazagão (3.45\%), Serra do Navio (6.18\%), Pedra Branca do Amapari (6.38\%) and Santana (17.24\%); similar to the rate observed in Macapá (30\%); and lower than what was reported in Porto Grande (45.50\%) (Deus et al. 2009, Silva et al. 2010). This work provides the first record of parasitism of A. serpentina by D. areolatus in manilkara fruits in Brazil (Table 1). Manilkara was already known to be a host of $A$. serpentina in Amapá, but without association with parasitoids (Deus et al. 2009)

Low parasitism rates were observed in hog plum (0.6 to 5.3\%). These values are lower than those reported for the same host in the municipalities of Itaubal do Piririm (11.9\%), Ferreira Gomes (21.7\%), and Macapá (23.6\%) (Silva et al. 2005, 2007a, Silva \& Silva 2007).
Fruit flies in hog plum, quina and guava showed the highest diversity of parasitoids. Anastrepha atrigona is strongly associated with quina (Deus et al. 2009), which is infested exclusively by this species in Amapá (Silva et al. 2011).

\section{Acknowledgements}

The authors thank the Agência de Desenvolvimento da Amazônia (ADA) and the Secretaria de Estado da Ciência e Tecnologia do Amapá for financial support to their research. We also thank Mr. Carlos Alberto Moraes, a staff member at Embrapa Amapá, for assistance in the field.

\section{References}

ALUJA, M. 1999. Fruit fly (Diptera: Tephritidae) research in Latin America: myths, realities and dreams. An. Soc. Entomol. Bras. 28(4):565-594. http://dx.doi.org/10.1590/S0301-80591999000400001

CANAL, N.A. \& ZUCCHI, R.A. 2000. Parasitóides - Braconidae. In Moscas-das-frutas de importância econômica no Brasil: conhecimento básico e aplicado (A. Malavasi \& R.A. Zucchi, Ed.). Holos, Ribeirão Preto, p.119-126.

CREÃO, M.I.P. 2003. Moscas-das-frutas (Diptera: Tephritidae): espécies, distribuição, medidas da fauna e seus parasitóides (Hymenoptera: Braconidae) no Estado do Amapá. Dissertação de Mestrado, Universidade do Amazonas, Manaus.

DEUS, E.G., SILVA, R.A., NASCIMENTO, D.B., MARINHO, C.F. \& ZUCCHI, R.A. 2009. Hospedeiros e parasitoides de espécies de Anastrepha (Diptera, Tephritidae) em dois municípios do Estado do Amapá. Rev. Agric. 84(3):194-203.

LEONEL JUNIOR, F.L., ZUCCHI, R.A. \& WHARTON, R.A. 1995 Distribution and tephritid hosts (Diptera) of braconid parasitoids (Hymenoptera) in Brazil. Int. J. Pest Manag. 41:208-213. http://dx.doi. org/10.1080/09670879509371951

MARINHO, C.F. 2009. Análises morfométricas e moleculares de espécies de Doryctobracon Enderlein e Opius Wesmael (Hymenoptera: Braconidae), parasitóides de mosca-das-frutas (Diptera: Tephritidae). Tese de Doutorado, Universidade de São Paulo, Piracicaba. 
MATRANGOLO, W.J.R., NASCIMENTO, A.S., CARVALHO, A.S., MELO, E.D. \& JESUS, M. 1998. Parasitóides de moscas-das-frutas (Diptera: Tephritidae) associados a fruteiras tropicais. An. Soc. Entomol. Bras. 27(4):593-603. http://dx.doi.org/10.1590/S030180591998000400012

OVRUSKI, S.M., ALUJA, M., SINVINSKI, J. \& WHARTON, R.A. 2000. Hymenopteran parasitoids on fruit-infesting Tephritidae (Diptera) in Latin America and the Southern United States: diversity, distribution, taxonomic status and their use in fruit fly biological control. Int. Pest Manag. Rev. 5(2):81-107. http://dx.doi.org/10.1023/A:1009652431251

SILVA, R.A. \& SILVA, W.R. 2005. Conhecimento atual sobre parasitóides de moscas-das-frutas no Estado do Amapá. Embrapa Amapá, Macapá, 24 p. (Documentos, 55).

SILVA, W.R. \& SILVA, R.A. 2007. Levantamento de moscas-das-frutas e de seus parasitóides no Município de Ferreira Gomes, Estado do Amapá. Cienc. Rural 37(1):265-268. http://dx.doi.org/10.1590/S010384782007000100043

SILVA, R.A., SILVA, W.R., NASCIMENTO, D.B. \& SILVA, C.A. 2005. Levantamento de moscas-das-frutas e seus parasitóides em frutos de taperebazeiro na Área de Proteção Ambiental do Rio Curiaú, Macapá, Estado do Amapá. Embrapa Amapá, Macapá, 5 p. (Comunicado Técnico, 116).

SILVA, R.A., NASCIMENTO, D.B., DEUS, E.G., SOUZA, G.D. \& OLIVEIRA, L.S.P. 2007a. Hospedeiros e parasitóides de Anastrepha spp. (Diptera: Tephritidae) em Itaubal do Piririm, Estado do Amapá. Ciênc. Rural 37(2):557-560. http://dx.doi.org/10.1590/S010384782007000200041

SILVA, R.A., XAVIER, S.L.O., SOUZA FILHO, M.F., SILVA, W.R., NASCIMENTO, D.B. \& DEUS, E.G. 2007b. Frutíferas hospedeiras e parasitóides (Hym., Braconidae) de Anastrepha spp. (Dip., Tephritidae) na Ilha de Santana, Estado do Amapá, Brasil. Arq. Inst. Biol. 74(2):153-156.
SILVA, R.A., PEREIRA, J.D.B., LEMOS, L.N. \& SILVA, W.R. 2010. Espécies de Anastrepha (Diptera: Tephritidae) associadas a frutíferas de expressão socioeconômica no estado do Amapá, Brasil. Rev. Agric. 85(3):207-217.

SIlVA, R.A., DEUS, E.G., PEREIRA, J.D.B., JESUS, C.R., SOUZA-FILHO, M.F. \& ZUCCHI, R.A. 2011. Conhecimento sobre moscas-das-frutas no Estado do Amapá. In Moscas-das-frutas na Amazônia brasileira: diversidade, hospedeiros e inimigos naturais (R.A. Silva, W.P. Lemos \& R.A. Zucchi, Ed.). Embrapa Amapá, Macapá, p. 223-236.

URAMOTO, K., MARTINS, D.S. \& ZUCCHI, R.A. 2008. Fruit flies (Diptera, Tephritidae) and their associations with native host plants in a remnant area of the highly endangered Atlantic Rain Forest in the State of Espírito Santo, Brazil. Bull. Entomol. Res. 98:457-466. PMid:18439337. http:// dx.doi.org/10.1017/S0007485308005774

XAVIER, S.L.O., SILVA, R.A., SOUZA FILHO, M.F. \& SARQUIS, R.S.F.R. 2006. New records of host plant for Anastrepha atrigona Hendel (Dip., Tephritidae) in the Brazilian Amazon. In International Symposium on Fruit Flies of Economic Importance, 7., Meeting of the Working Group on Fruit Flies of the Western Hemisphere, 6. Moscamed, Salvador. 1 CD ROM

ZUCCHI, R.A. 2000. Espécies de Anastrepha, sinonímias, plantas hospedeiras e parasitoides. In Moscas-das-frutas de importância econômica no Brasil: conhecimento básico e aplicado (A. Malavasi \& R.A. Zucchi, Ed.). Holos, Ribeirão Preto, p. 41-48.

ZUCCHI, R.A., MARINHO, C.F \& SILVA, R.A. 2011. First record of the fruit fly parasitoid Doryctobracon crawfordi (Viereck) (Hym., Braconidae) in Brazil. Neotrop. Entomol. 40(6): in press. 